\title{
GAMIFICATION AND UBERIZED WORK IN APPLICATION COMPANIES
}

Uberization, the gig economy, on-demand economy, platform economy, and crowdsourcing are examples of terms used in several academic works to refer to the large number of transformations promoted by information and communication technologies (hereinafter abbreviated as "ICT") in the universes of organizations and work, although there is no consensus on their meanings (Filgueiras \& Antunes, 2020, p. 30). The term "uberization" (Slee, 2017) refers directly to Uber, but is not restricted to it, since it is used in a broad sense as a global trend that affects occupations with different qualifications and incomes, materializing the processes and subjectivities associated with a new neoliberal way of the world (Dardot \& Laval, 2016). Sociologist Ana Claudia Moreira coined the expression "uberism" to refer to a model of work organization and management, akin to Taylorism, Fordism and Toyotism, which emerged from the foundation of ICT and digital platforms (Santos, 2020). Like Uber, Loggi, iFood, Rappi, and Lyft are also examples of "application companies” (Abílio, 2019).

Initially, the transformations promoted by ICTs offered workers countless opportunities for overcoming the rigidity of traditional jobs, for example, and allowing people to accumulate activities and generate extra income. Income generation supposedly happens in a fun way and in the free time of the service provider (Stefano, 2017), or when the provider so wishes (Valenduc, 2019), by way of their performance as a creator or a partner of the application company. Another advantage of the platform model is the reduction in distance between income opportunities and workers, who can carry out their activities regardless of their geographical location (Kittur et al., 2013), as in the case of the Amazon Mechanical Turk micro-work platform (Moreschi, Pereira, \& Cozman, 2020). Distance has also become smaller between service providers and consumers thanks to digital platforms and applications that reduce prices and speed up the provision of a huge range of services (Manyika et al., 2016), from transportation, esthetics and cleaning to general services and deliveries. More advantages appear in this list, such as the democratization of the means of production, and the promotion of neo-entrepreneurship (with opportunities for small businesses, as mentioned by Filgueiras \& Antunes, 2020).

Despite the initial enthusiasm associated with the autonomy, economic opportunities and equity (Schor $\&$ Eddy, 2020) that are promoted by digital platforms, the current context, especially considering the COVID-19 pandemic, points to a dependence on some services, such as deliveries, in addition to showing that, despite some positive results, many who work under such conditions suffer the negative consequences of the platform economy. This new economy is led by startups that define themselves as technology companies and intermediaries between consumers and producers/service providers (Filgueiras \& Antunes, 2020), and that structure themselves 
on an extractive capitalist model (Morrell, Espelt, \& Cano, 2020). The opportunities mentioned in the previous paragraph contrast with low wages, a lack of self-determination (Schor \& Eddy, 2020), long working hours, and the transfer of the costs and risks associated with the activities to workers, who need to be managed, controlled and subordinated (Abílio, 2019) after adhering to the terms and conditions of use of the platforms. In such a context, in which the sources and structures of meanings (such as practices, values, rituals and hierarchies, for example) are influenced, created by or expressed through ICTs (Kozinets, 2019, p. 621), gamification is one of the tools that digital platforms use to control, manage and oversee their "partners".

In the past eight years, "gamification" has taken organizations, the media and academic research by storm (e.g., Dymek \& Zackariasson, 2016a). A search on Google Scholar shows about 51,000 results for the topic between 2002 and 2020. In this year (2020), we highlight the work of Doorn and Chen (forthcoming), which deals with gamification in the context of two food delivery platforms, one Chinese and one North American; and that of Abílio, who defines gamification as "transferring risks and stimulating productivity, which are also new forms of control over work" (Abílio, 2020, p. 20). This is a challenge for those who take risks working without any guarantees, since it is up to the application company to define the rules of the game and, possibly, the winner (which suggests that instead of algorithmic randomness, there is a programmed distribution of bonuses, for example). The most immediate objective of gamification is to promote the engagement of workers and consumers by way of challenges and competitions that are based on performance and incentives and, as a result, to obtain better results (Dymek \& Zackariasson, 2016b). The seminal definition of Deterding, Khaled, Nacke and Dixon (2011) inspired authors like Woodcock and Johnson (2018) to apprehend gamification as the application of game systems (competition, prizes, the quantification of user behavior) in unrelated domains, such as those of work.

In this reflection, we analyze the relationship between gamification and uberized work in the operations of application companies, digital platforms (Srnicek, 2017) that epitomize a new business model with their infrastructure linked to ICTs and algorithms. We start from a critical position with regard to these themes, since gamification is commonly approached in management literature as a strategy that is capable of promoting engagement and satisfaction, and increasing employee performance in a kind of win-win situation for organizations and their employees. As gamification also has great potential for solving problems by influencing human motivation and behavior (Zichermann \& Cunningham, 2011), we wonder what the consequences of combining this strategy with "uberism" might be in a context in which the precariousness of work is associated with surveillance capitalism (Zuboff, 2015) and algorithmic governance (Castro, 2018). Thus, we aim to discuss gamification as a tool for work management, control and subordination, and also associated with algorithmic opacity (Bridle, 2019), a multitude of workers, and the figure of the just-in-time worker (Abílio, 2019). Finally, we will briefly highlight some of the options for the platform economy that can minimize the use of gamification, such as the possibilities afforded by a sustainable platform economy and platform cooperativism (Morrell et al., 2020; Scholz, 2016; Schor \& Eddy, 2020).

\section{GAMIFICATION AND PLATFORMS}

The term "gamification" emerged in 2002 as the process by which the methods, metaphors, values and attributes of games are able to permeate our society (Fuchs, 2014). Employee-of-the-month signs and loyalty programs are examples of pre-digital gamification (Vesa \& Harviainen, 2019). On the one hand, this strategy is extolled as a 
fun solution for engaging and motivating consumers and workers (McGonigal, 2011). Structures, organizations or systems become more intrinsically motivating, and support the general creation of value (Vesa, Hamari, Harviainen, \& Warmelinl, 2017). On the other hand, criticisms and doubts about gamification have arisen that question its effectiveness without pre-existing motivation (e.g., Hamari, 2013), and examine its long-term effects (e.g., Koivisto \& Hamari, 2014).

The difference proposed by Caillois (2001) between ludus (more explicit forms of games guided by rules, without negative connotations) and paida (free play, improvisation, spontaneity, and impulsiveness) guided some of these criticisms. For example, Bogost (2011) coined the expression "exploitationware" as a synonym for gamification, while Escribano (2013) states that gamification is nothing more than a "ludictatorship". Woodcock and Johnson (2018) highlight two distinct types of gamification: one coming from above (gamification-fromabove), associated with the concept of ludus, which emphasizes forms of interaction and feedback drawn from games, but separate from their original playful contexts, and one coming from below (gamification-from-below), which is identified with playful contexts associated with paida that aim to make work easier and, at certain times, serving as a resistance practice. The gamification of work seems to imbue it with a behavioral, virtual, and instrumental bias, making it a competitive and (in theory) a fun game, which rewards workers with immaterial prestige rewards (Vesa et al., 2017), such as virtual badges for service excellence or for being fun drivers, as in the case of Uber (Scheiber, 2017).

Our position is that the gamification associated with the uberized work of application companies results in the intensification and exploitation of labor, which is evidence of the new form that management, control and surveillance practices take in the techno-cultural context. In this sense, the Utopian promise of the information society, of emancipated social insertion in and through work, collapses (Braga, 2009, p. 65). Gamification crystallizes through the uberization of work, making it difficult to identify, as it does not materialize in a disciplinary space (such as a factory). Everything happens by way of apps, with minimal human contact, and in an automated way. Overt surveillance becomes a fundamental element for the effectiveness of gamification, and is made possible by digital platforms, which act as intermediaries between the job offer and the service demand, exhibiting monopolistic tendencies that result from network effects (the greater the number of users, the more valuable the platform, and the better its algorithms) (Srnicek, 2017). Thus, when thinking about gamification, we must pay attention to the scope of this strategy vis-à-vis the work process in the application companies.

We know that capitalism is restructured from time to time and that since 2008 its latest version has been associated with a narrative that focuses on the change in, and rise of technology, and that since then, we have lived in an information economy that Srnicek (2017) calls the "platform economy", which is characterized by the extraction and use of a new form of raw material: data. To say that data is the oil of the 21st century may be a cliché, but considering the scale of the digital transformations underway, we cannot underestimate it (Morozov, 2018, p. 8). Like oil, data must be extracted and refined before they can be used. This process involves their capture, registration in some type of material medium and maintenance in mass storage systems (Srnicek, 2017). Platforms are designed to govern the possibilities of interaction, with the rules for the development of their products and services defined by their owner, which indicates that they are not an empty or apolitical space (Srnicek, 2017).

The term "platform" itself establishes a way of being that sanctions a particular state of affairs, discursively placing company services and technologies in the context of financial, cultural and regulatory demands (Gillespie, 2010, p. 349). This framework is strategic, as it enables application companies to search for current and future 
profits at a regulatory point between the legislative protections that are of benefit to them and the obligations that are not, thus presenting a cultural imaginary in which their services make sense to their users and to society as a whole (Gillespie, 2010, p. 348). Thus, the platforms establish "the very criteria by which these technologies will be judged" (Gillespie, 2010, p. 359), taking the form of "a progressive and egalitarian arrangement, promising to support those who stand upon it" (Gillespie, 2010, p. 350).

\section{SURVEILLANCE AND ALGORITHMIC GOVERNANCE OF THE JUST-IN-TIME WORIKER}

Data collection and analysis must be understood as "a dynamic process where existing surveillance and profiling systems and personal information continuously inform each other with each new interaction between the system and consumers" (Pridmore \& Zwick, 2011, p. 272). As a result, application companies customize and structure the world in a non-transparent way (Morozov, 2018, p. 53), through "reality mining" (Zuboff 2015). The mere knowledge of what people do all the time is extrapolated, creating the possibility of intervention and behavior change so that

"what is real and what is the outcome of real-time techno-cybernetic manipulation becomes indistinguishable" (Charitsis, Zwick, \& Bradshaw, 2018, p. 822). This also applies to the "partners" of the application companies, who are simultaneously both consumers of the ICT they use, and workers who adhere (emphasis added) to it (since no contract is signed between the parties).

The operation of digital platforms was made possible, among other factors, by the techno-cultural scenario and operations associated with surveillance capitalism (Zuboff, 2015), thus referring us to the concept of control society and the "progressive and dispersed introduction of a new regime of domination" (Deleuze, 1992, p. 225). Surveillance capitalism establishes a ubiquitous institutional regime, a new type of invisible hand, called "Big Other", which annihilates the freedoms gained through the institution of the rule of law, and is configured as a "regime of independent and independently controlled facts that supplants the need for contracts, governance, and the dynamism of a market democracy" (Zuboff, 2015, p. 81). A future adapted to the normalization of chaos and terror emerges as a substitute for the "community of equals bound by laws in the inevitable and ultimately fruitful human struggle against uncertainty" (Zuboff, 2015, p. 81). Zuboff's forecast also contemplates the establishment of a compliance system based on rewards and punishments that contributes to the accumulation "not only [of] surveillance assets and capital, but also [of] rights" (Zuboff, 2015, p. 83), in as far as individual rights are taken from individuals by Big Other and subsequently redistributed unilaterally.

Despite what Zuboff (2015) says about the lack of governance, Castro (2018) points out "a new form of governance exercised by organizations through algorithms" (Castro, 2018, p. 169, in italics in the original) that involves mining large volumes of data and metadata (hence the term "big data"), which are captured by activities mediated by application companies. It is algorithmic governance that reflects a generalization of management instruments, creating a kind of government without government, and distancing itself from the idea of government as State administration, thus favoring horizontal or networked command styles (Castro, 2018, p. 169). We also emphasize that algorithmic governance finds support from a technocratic point of view, according to which "political decisions are based on neutral facts or rational arguments" (Lemke, 2007, p. 54). This observation leads us to the work of Gillespie (2010) and Srnicek (2017) on how platforms are instituted, including discursively, as technology companies that mediate demand and supply. Associated with this institution is the opacity of ICT and 
its algorithms, understood as a set of instructions for carrying out a task, and increasingly entrusted with decisions, evaluations and analyses that have a direct impact on our lives (Doneda \& Almeida, 2018, p. 141).

Algorithmic work is so complex that technological opacity is attributed to it, since the algorithm itself is endowed with automatic learning, and is able to take the decision alone "to reorganize its internal functioning based on the data it is analyzing" (Doneda \& Almeida, 2018, p. 142). In this sense, we talk about the "opacity of technological systems" (Bridle, 2019, p. 132), that is, contemporary technology produces effects in the real world that are almost imperceptible a priori and, therefore, more difficult to be dimensioned by us (Bridle, 2019, p. 137). In the context of uberism, it is common for workers not to understand the functioning of various activities that are part of their routines, such as dynamic pricing, platform-promoted expulsions, the distribution of races and tasks, etc. (Abílio, 2019, p. 3). The presence of algorithms in application companies is explicitly associated with opaque and unpredictable management and automatic decision-making systems that replace supervisors and shift managers (Mason, 2019). The logic of the algorithm is unknown to the platform's "partners", who can only speculate in virtual forums and on social media about its operation, and who discuss tactics to "deceive" it, such as by interrupting mass work that aims to "force" the algorithm to generate higher tariffs. However, within the context observed here, the traditional technique of interrupting work loses the connotation of fighting exploitation, and becomes a mere attempt at gaming the game (cheating the algorithmic game), which gives workers a feeling of control over the work process while not evidencing a position against capitalist logic, only against obstacles within the game itself (Mason, 2019).

It is interesting to think about this statement in the light of the demands of delivery workers (known as "motofretistas" in Brazil) who are responsible for the stoppages carried out in July 2020 in the midst of the COVID19 pandemic, when delivery services became essential. According to the Instagram profile "Treta no Trampo" (@ tretanotrampo), on July 21, 2020 "the fight is to earn more, not to become a CLT or a "placa vermelha" and end up earning less. Nobody wants fixed hours and to have a boss". The goal of delivery workers is real autonomy, which would make it possible to negotiate the price of their labor; after all, it is impossible to negotiate with the app or with the algorithm. Evidence of this is seen in the punishment that is applied when tasks are refused. Delivery workers and app drivers complain that they stop getting "gigs", that their scores are negatively affected, and that they are eventually blocked. On the one hand, even though the challenge workers face because of algorithmic management is evident, none of them want to see their work regulated by the CLT, and on the other, Labor Reform (Law 13,467/2017) legalized and started encouraging uberism (also understood as informal working conditions), when it recognized intermittent work (Krein, Abílio, Freitas, Borsari, \& Cruz, 2018), for example. In this sense, in addition to the elimination of guarantees acquired through the rule of law by the info-technological Big Other (Zuboff, 2015), the State itself now collaborates so that these guarantees (among them, labor guarantees) are removed from the current legislation.

Algorithmic management has become a new facet of the world of work, with gamification as a strategy, thus allowing work to be increasingly dispersed and its management and control increasingly concentrated ("organization through dispersion", Harvey, 1992). Dispersion is represented by the multitude of workers who are available and engaged, and who adhere to the application company, bear the risks and costs of their activity, and have no guarantees, rights or security (Abílio, 2019). They are also called "just-in-time workers" (Abílio, 2019, p. 4), since application companies are on-demand companies. The formation of a multitude of workers represents a new stage in the outsourcing of work, since there are no more subcontractors, just a multitude of "partners" 
who constantly manage and seek to differentiate themselves individually by way of longer working hours and by assimilating higher costs. These are "self-entrepreneurs", neo-subjects modulated by the "company culture" (Dardot \& Laval, 2016, p. 328), who manage their own work in a subordinate manner (Abílio, 2019, p. 5).

Governance or algorithmic management allows for greater predictability of the behavior of the multitude of workers, and it is precisely this predictability that makes it possible to govern the mass, which is traditionally associated with disorder (Castro, 2018). From the numerous movements monitored by the apps and their algorithms, "assumptions are made about future patterns, which are projected on the present as their itinerary and guide, causing the preemption of uncertainty by means of measurability, which in turn paves the way for risk management" (Castro, 2018, p. 175). In this sense, "information capitalism aims to predict and modify human behavior as a means to produce revenue and market control” (Zuboff, 2015, p. 75).

\section{UBERISM AND GAMIFIED EXPERIMENTS}

Gamification is a tool that hides work under layers of challenges and games, a concept known as playbor, which is a neologism that indicates the overlap between work and leisure, between production and consumption, which is capable of making work as addictive as video games (Scholz, 2017). The experimental character of the gamified strategies of application companies is emphasized by authors and commentators: Scheiber (2017) writes about Uber, while Mason (2019) talks about his experience working for Lyft. Scheiber (2017) is explicit in stating that Uber is stealthily involved in behavioral experiments to manipulate its drivers in order to achieve corporate growth. On the one hand the company insists on saying that its drivers are bound by contracts, that they are partners or entrepreneurs who enjoy flexibility, and who connect to consumers who need their services by way of the platform (paying a commission of between $20 \%$ and $30 \%$, according to Rosenblat and Stark, 2016). On the other hand, the application company needs to compete with others, which means serving its customers in the shortest time possible and at the lowest possible cost. As they do not have the means of coercion of traditional organizations, gamification is used to encourage profitable behavior in their "collaborators", even though these can also be harmful to workers.

Drivers receive "texts, emails, pop-ups, and carefully designed graphics to keep them behind the wheel, and direct them, ostensibly, to areas of highest demand" (Süsser, Roessler \& Nissenbaum, 2019, p.8). In this way, as in video games, platform workers are discreetly driven, resulting in more emotional engagement, and more investment in completing tasks. We also remember that contact with the company is mostly by way of the app, with no human interaction, enabling all activities to be quantified and transformed into data that are collected and analyzed, thus suggesting the possibility of the unlimited implementation of gamified strategies. We list below examples of these strategies, remembering that this is not an exhaustive list. In addition, we draw attention to the obsolescence that surrounds studies on new media and ICT (Crary, 2013), which signals the expansion of the range of gamified techniques over time, making an in-depth investigation fundamental for understanding how the universe of work is being reconfigured through the acceleration promoted by ICT, and the new forms of work management and control that have emerged in this context.

In addition to immaterial rewards, such as fun driver badges (Scheiber, 2017), elaborate graphics, which show drivers those areas where higher rates are likely, are considered a gamification technique (Süsser et al., 2019). Drivers are attracted by the possibility of more profitable trips (“dynamic pricing”), but the chances of getting 
one are slim and extremely unpredictable, because the highlighted areas appear and disappear in a matter of minutes (Mason, 2019). Apparently, the tactic keeps drivers driving to meet the demand (Calo \& Rosenblat, 2017, p. 1662 call this technique the "bait and whip mechanism"). This unpredictability is addictive, and is also widely exploited in games of chance to ensure players place just one more bet (Mason, 2019).

The just-in-time, or on-demand worker is a 'kept working' by techniques such as notifications that are received when, for example, they are ready to disconnect from the app: "Are you sure you want to go offline? Demand is very high in your area. Make more money, don't stop now!” (Rosenblat \& Stark, 2016, p. 3768). Another common notification warns the worker that they are reaching an arbitrary earning goal: "You are $\$ 10$ from making \$330!", accompanied by commands just below the message (and highlighted), which offer the driver two options - disconnect or continue driving (Scheiber, 2017), as on a video game screen. These are "attempts to exploit a well-known decision-making vulnerability - people's preoccupation with goals” (Süsser et al., 2019, p. 8). Similar effects are achieved by the interactive feature of apps that show drivers "work status (hours, earnings, rides, etc.) in game-like formats that are known for their power to keep players at the game console, and, presumably, drivers at the wheel” (Süsser et al., 2019, p. 8).

One technique adopted by Uber that is considered addictive (Mason, 2019; Scheiber, 2017; Süsser et al., 2019) is the forward dispatch (an automatic and standard feature, which Uber guarantees can be deactivated by the driver, although it is automatically reactivated after each break, according to Scheiber, 2017), that is, before finishing a trip drivers are informed of other requests, which makes them practically irresistible. This technique is comparable to that used by streaming services, such as Netflix and Amazon Prime, which promotes a new way of consuming called "binge watching" (e.g., Pittman \& Sheehan, 2015, for "marathon series" in Portuguese). In the context of uberized work, the technique certainly promotes a new (and addictive) way of working, which reduces the waiting time for consumers while overriding the drivers' self-control (Scheiber, 2017).

As a last example, we point to the evaluation system that apps use to classify their drivers, which is associated with surveillance and worker management. In addition to outsourcing the role of manager to consumers (Rosenblat \& Stark, 2016), creating an economy of reputation (Slee, 2017), the evaluations highlight the system of constant monitoring of drivers' work in order to identify and create flows of efficient work, as in the Taylorist tradition (Rosenblat \& Stark, 2016, p. 3772). At the heart of techno-culture, surveillance is a way of collecting data that are produced by workers and users of apps. These data make it possible for other gamified techniques to be implemented, thus avoiding direct disciplinary measures through the use of weekly performance metrics, for example (Rosenblat \& Stark, 2016, p. 3772). Job stability is threatened. Workers simply speculate in communities on social media how these evaluations are made. Some companies distribute tasks in high-demand times according to accumulated assessments. When the score drops, calls become scarce, or workers are disconnected by the application company (Ordaz, 2019).

Trying to maintain high averages, workers resort to what is described as emotional work, the combination of friendly attempts at conversation with eye contact in order to guess the preferences of passengers in exchange for good assessments instead of tips (Rosenblat \& Stark, 2016, p. 3775). The commitment to please users becomes an obsession as the assessment reports arrive, showing a drop in the average (Mason, 2019). As ratings are calculated on the basis of the last 100 trips, drivers feel compelled to drive even further in exchange for better ratings (Mason, 2019). Abílio (2019, p. 4) points out that evaluations act as an informal certification that affects the professional identity of the worker, that is, his/her professional recognition is closely linked to the ranking over time; so even the possibility of having access to future work is at stake. 
The experiments conducted by the application companies with their "partners" reveal "human vulnerability to forms of irrational, biased and bounded thinking, as well as tendencies towards compulsive and even addictive ruts" (Süsser et al., 2019, p. 9). Mason (2019) goes further, arguing that these on-demand companies adopt the same elements as betting companies with the intention of keeping their workers connected and available for longer periods, and checking the app frequently. In theory, surveillance helps triangulate the data produced at each interaction with other demographic data, forming profiles that allow drivers to receive personalized communication. However, there are authors (e.g., Schüll, 2014) who argue that the ludic loop, a feeling of unpredictability that is addictive, is responsible for keeping workers at their disposal. After all, they never know when dynamic pricing areas will emerge or when the next task will arrive that will allow them to earn a bonus. Thus, workers are conditioned to do just one more trip, like the player who always needs to play one last round. There seems to be a time dimension involving work management and control that deserves to be investigated, which combines with the surveillance and operation of the platforms. There is a fear, therefore, of a return to an era prior to the New Deal (Scheiber, 2017), when there was a frightening asymmetry of power between organizations and workers, represented by the absence of guarantees and security, enabling them to be exploited. We are facing a possible digital easement, which is very similar to the working conditions of the 19th century (Ordaz, 2019).

In conclusion, we believe that uberism is a global trend in the world of work (Abílio, 2019) that is appearing in other contexts associated with the gig economy, such as domestic work, micro-work and online freelancing (Woodcock \& Graham, 2020). In all these scenarios, gamification intervenes, changing the form of worker management and control. Recent studies, however, suggest the possibility of a sustainable platform economy, as well as platform cooperativism (Morrell et al., 2020; Scholz, 2016; Schor \& Eddy, 2020), contexts in which the use of gamified techniques is greatly reduced: four of the 20 platforms that were part of the study by Morrell et al. (2020) use gamification. Three of these four platforms are unicorns (that is, startups valued at $\$ 1$ billion before going public), and one is an alternative design platform. Two of the 20 stated that their employees can reject both algorithmic management and gamified techniques when these aspects are present (Morrell et al., 2020). These two platforms are unusual, however (that is, it is impossible to reject both algorithmic management and gamification when working for unicorn digital platforms, according to Morrell et al. 2020).

In turn, platform cooperativism, which emerges from the values of the Social and Solidarity Economy, and the principles of cooperativism, is thought to be a truly collaborative alternative (Morrell et al., 2020). Schor and Eddy (2020) investigated non-profit platforms that aim to promote social benefits and that, despite using the same technology as other platforms but in low-cost versions, have either been unsuccessful, or have experienced very slow growth. In any case, the expectation is that gamification in these models is reduced or even optional. The attempt to create delivery cooperatives in Brazil exists and relies on the voluntary work of professionals from different areas (lawyers, programmers, and economists, among others), despite the high initial cost of developing a simplified app (about BRL 500,000, according to the Época Negócios magazine website, 2020).

\section{REFERENCES}

Abílio, L. C. (2019). Uberização: Do empreendedorismo para - autogerenciamento subordinado. Psicoperspectivas, 18(3), 1-11. doi: 10.5027/psicoperspectivas-vol18-issue3fulltext-1674
Abílio, L. C. (2020). Plataformas digitais e uberização: Globalização de um Sul administrado? Contracampo, 39(1), 12-26. doi: 10.22409/contracampo.v39i1.38579 
Bogost, I. (2011). Gamification is bullshit: My position statement at the Wharton Gamification Symposium. Retrieved from http://bogost.com/writing/blog/gamification_is_bullshit/

Braga, R. (2009). A vingança de Braveman: 0 infotaylorismo como contratempo. In R. Antunes, \& R. Braga (Orgs.), Infoproletários: Degradação real do trabalho virtual, 59-88 São Paulo, SP: Boitempo.

Bridle, J. (2019). A nova idade das trevas: A tecnologia e o fim do futuro. São Paulo, SP: Todavia.

Caillois, R. (2001). Man, play and games. Champaign, Illinois: University of Illinois.

Calo, R., \& Rosenblat, A. (2017). Taking economy: Uber, information, and power. Columbia Law Review,117(6), 1623-1690. Retrieved from https://columbialawreview.org/ content/the-taking-economy-uber-information-and-power/

Castro, J. C. L. (2018). Redes sociais como modelo de governança algorítmica. MATRIZes, 12(2), 165-191. doi: 10.11606/ issn.1982-816o.v12i2p165-191

Charitsis, V., Zwick, D., \& Bradshaw, A. (2018) Creating worlds that create audiences: Theorising personal data markets in the age of communicative capitalism. Triple C, 16(2), 820834. doi: 10.31269/triplec.v16i2.1041

Crary, J. (2013). 24/7: Late capitalism and the ends of sleep. London, UK: Verso.

Dardot, P., \& Laval, C. (2016). A nova razão do mundo: Ensaio sobre a sociedade neoliberal. São Paulo, SP: Boitempo.

Deleuze, G. (1992). Conversações, 1972-1990. São Paulo, SP: Editora 34 .

Deterding, S., Khaled, R., Nacke, L. E., \& Dixon, D. (2011). Gamification: Toward a definition. Retrieved from http:// gamication-research.org/wp-content/uploads/2011/04/02 Deterding-Khaled-Nacke-Dixon.pdf

Doneda, D., \& Almeida, V. A. F. (2018). O que é a governança de algoritmos? In F. Bruno, B. Cardoso, M. Kanashiro, L. Guilhon, \& L. Melgaço (Orgs.), Tecnopolíticas da vigilância: Perspectivas da margem. São Paulo, SP: Boitempo.

Doorn, N. Van, \& Chen, J. Y. (2020, no prelo). Odds stacked against workers: Labor process gamification on Chinese and American food delivery platforms. Socio-Economic Review. Retrieved from https://admin.platformlabor.net/ output/labor-process-gamification-china-us-food-deliveryplatforms/Odds\%20Stacked\%20Against\%20Workers_prepub.pdf

Dymek, M., \& Zackariasson, P. (2016a). The business of gamification: A critical analysis. New York, USA: Routledge.

Dymek, M., \& Zackariasson, P. (2016b). Work hard, play hard. In M. Dymek, \& P. Zackariasson (eds), The business of gamification: A critical analysis, [ePub], xi-xxi,New York, USA: Routledge.

Época Negócios. (2020). "Adeus, iFood": Entregadores tentam criar cooperativa para trabalhar sem patrão. Retrieved from https://epocanegocios.globo.com/Carreira/noticia/2020/07/ adeus-ifood-entregadores-tentam-criar-cooperativa-para-trabalhar-sem-patrao.html
Escribano, F. (2013). Gamification versus ludictatorship. Revista de Comunicación, 5, 58-72. Retrieved from http:// revistadigitalis.uvic.cat/índex.php/obradigital/article/ view/22

Filgueiras, V., \& Antunes, R. (2020). Plataformas digitais, uberização do trabalho e regulação no capitalismo contemporâneo. Contracampo, 39(1), 27-43. doi: 10.22409/ contracampo.v39i1.38901

Fuchs, M. (2014). Predigital precursors of gamification. In M. Fuchs, S. Fizek, P. Ruffino, \& N. Schrape (Eds.), Rethinking gamification. Hybrid Publishing Lab, Centre for Digital Cultures, United Kingdom: Lightning Source UK Ltd, 119-140.

Gillespie, T. (2010). The politics of 'platforms'. New Media and Society, 12(3), 347-364. doi 10.1177/1461444809342738

Hamari, J. (2013). Transforming Homo economicus into Homo ludens: A field experiment on gamification in a utilitarian peerto-peer trading service. Electronic Commerce Research and Applications, 12, 236-245. doi: 10.1016/j.elerap.2013.01.004

Harvey, D. (1992). A condição pós-moderna: Uma pesquisa sobre as origens da mudança cultural. São Paulo, SP: Loyola.

Kittur, A., Nickerson, J. V., Bernstein, M., Gerber, E., Shaw, A., Zimmerman, J., Lease, M., \& Horton, J. (2013, February 23-27). The future of crowd work. Proceedings of the ACM Conference on Computer Supported Coooperative Work, San Antonio, USA. Retrieved from https:// hci.stanford.edu/publications/2013/ CrowdWork/futureofcrowdwork-cscw2013.pdf

Koivisto, J., \& Hamari, J. (2014). Demographic differences in perceived benefits from gamification. Computer in Human Behavior, 35, 179-188. doi: 10.1016/j.chb.2014.03.007

Kozinets, R. V. (2019). Consuming tecnocultures: An extended JCR curation. Journal of Consumer Research, 46, 620-627. doi: 10.1093/jcr/uczo34

Krein, J. D., Abílio, L., Freitas, P., Borsari, P., \& Cruz, R. (2018). Flexibilização das relações de trabalho: Insegurança para os trabalhadores. Revista do Tribunal Regional do Trabalho da 15 ${ }^{\underline{a}}$ Região, (52), 41-66. Retrieved from https://juslaboris.tst. jus.br/handle/20.500.12178/141969

Lemke, T. (2007). An indigestible meal? Foucault, governmentality and state theory. Distinktion, 8(2), 43-64. doi: $10.1080 / 1600910 X .2007 .9672946$

Manyika, J., Lund, S., Bughin, S., Robinson, K., Mischke, J., \& Mahajan, D. (2016, October). Independent work: Choice, necessity, and the gig economy. Mckinsey Institute. Retrieved from https://www.mckinsey.com/featured-insights/ employment-and-growth/independent-work-choicenecessity-and-the-gig-economy

Mason, S. (2019). Chasing the pink. Logic, 6. Retrieved from https://logicmag.io/play/chasing-the-pink

McGonigal, J. (2011). Reality is broken: Why games make us better and how they can change the world. New York, USA: Penguin Books. 
Moreschi, B., Pereira, G., \& Cozman, F. G. (2020). The Brazilian workers in Amazon Mechanical Turk: Dreams and realities of ghost workers. Contracampo, 39(1), 46-64. doi: 10.22409/ contracampo.v39i1.38252

Morozov, E. (2018). Big Tech: A ascensão dos dados e a morte da política. São Paulo, SP: Ubu Editora

Morrell, M. F., Espelt, R., \& Cano, M. R. (2020). Sustainable platform economy: Connections with the sustainable development goals. Sustainability, 12(18), 7640. doi: $10.3390 /$ su 12187640

Ordaz, P. (2019). Os entregadores de comida são reféns do seu 'like'. Retrieved from https://brasil.elpais.com/ brasil/2019/01/23/economia/1548260634_440077.html

Pittman, M., \& Sheehan, K. (2015). Sprinting a media marathon: Uses and gratifications of binge-watching television through Netflix. First Monday, 2o(10). doi:10.5210/fm.v20i10.6138

Pridmore, J., \& Zwick, D. (2011). Editorial: Marketing and the rise of commercial consumer surveillance. Surveillance and Society, 8(3), 269-277. Retrieved from https://ojs.library. queensu.ca/index.php/surveillance-and-society/article/ view $/ 4163 / 4165$

Rosenblat, A., \& Stark, L. (2016). Algorithmic labor and information asymmetries: A case study of Uber's drivers. International Journal of Communication, 10, 3758-3784. Retrieved from https://ijoc.org/index.php/ijoc/article/ view/4892/1739

Santos, J. V. (2020). Uberismo e gaificação: Transformações do mundo do trabalho reveladas na greve dos entregadores. Instituto Humanitas Unisinos. Retrieved from http://www. ihu.unisinos.br/159-noticias/entrevistas/601125-uberismoe-gamificacao-transformacoes-do-mundo-do-trabalhoreveladas-na-greve-dos-entregadores-entrevista-especialcom-ana-claudia-moreira-cardoso

Scheiber, N. (2017). How Uber uses psychological tricks to push its drivers' buttons. N.Y. Times. Retrieved from https://www. nytimes.com/interactive/2017/04/02/technology/uberdrivers-psychological-tricks.html

Scholz, T. (2016). Cooperativismo de plataforma: Contestando a economia do compartilhamento corporativa. São Paulo, SP: Autonomia Literária.

Scholz, T. (2017). Uberworked and underpaid: How workers are disrupting the digital economy. Cambridge, UK: Polity Press.
Schor, J. B., \& Eddy, S. (2020). The just and democratic platform? Possibilities of platform cooperativism. Retrieved from https://www.bc.edu/content/dam/bc1/schools/mcas/ sociology/pdf/connected/Platform $\% 2$ oPossibilities $\% 20$ March\%201\%202020.pdf

Schüll, N. D. (2014). Addiction by design: Machine gambling in Las Vegas. Princeton, USA: Princeton University Press.

Slee, T. (2017). Uberização: A nova onda do trabalho precarizado. São Paulo, SP: Editora Elefante.

Srnicek, N. (2017). Platform capitalism [ePub]. Cambridge, UK: Polity Press.

Stefano, V. De. (2017). Labour is not a technology: Reasserting the declaration of Philadelphia in times of platform-work and gig-economy. IUSLabor, 2, 1-16. Retrieved from https://core. ac.uk/download/pdf/155003521.pdf

Süsser, D., Roessler, B., \& Nissenbaum, H. (2019). Online manipulation: Hidden influences in a digital world. Georgetown Law Techonology Review, 4(1), 1-45. Retrieved from https:// georgetownlawtechreview.org/online-manipulation-hiddeninfluences-in-a-digital-world/GLTR-01-2020/

Valenduc, G. (2019). New form of work and employment in the digital economy. In A. Serrano-Pascual, \& M. Jespen (Eds.), The deconstruction of employment as a political question. Brussels, Belgium: Palgrave Macmillan, 63-80.

Vesa, M., Hamari, J., Harviainen, J. T., \& Warmelink, H. (2017). Computer Games and Organization Studies. Organization Studies, 38(2), 273-284. doi: 10.1177/0170840616663242

Vesa, M., \& Harviainen, J. T. (2019). Gamification: Concepts, consequences, and critiques. Journal of Management Inquiry, 28(2), 128-130. doi: 10.1177/1056492618790911

Woodcock, J. \& Graham, M. (2020). The Gig Economy: A critical introduction [ePub]. Cambridge, UK: Polity Press.

Woodcock, J., \& Johnson, M. R. (2018). Gamification: What it is, and how to fight it. The Sociological Review, 66(3), 542-558. doi: $10.1177 / 0038026117728620$

Zichermann, G., \& Cunningham, C. (2011). Gamification by design: implementing game mechanics in web and mobile apps. Canada: O’Reilly Media, Inc.

Zuboff, S. (2015). Big Other: Surveillance capitalism and the prospects of an information civilization. Journal of Information Technology, 3o(1), 75-89. doi: 10.1057/jit.2015.5

\section{AUTHOR CONTRIBUTIONS}

Renata Couto de Azevedo de Oliveira worked on the research, writing and final revision of this theoretical essay manuscript. 